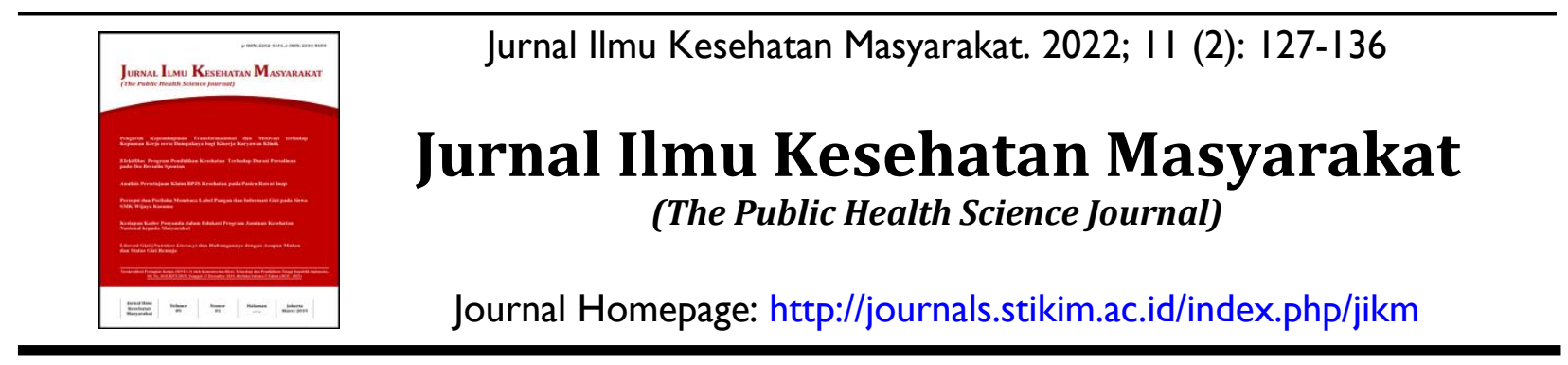

\title{
Literature Review: Determinan Kepatuhan Terhadap Protokol Kesehatan COVID-19 di Indonesia
}

\author{
Tanto', Handayani' \\ ${ }^{1,2}$ Program Studi IImu Kesehatan Masyarakat Sekolah Pascasarjana \\ Universitas Muhammadiyah Prof. Dr. Hamka
}

\begin{abstract}
Abstrak
Ketidakpatuhan pada protokol kesehatan COVID-19 di Indonesia masih menjadi penyebab tingginya angka penularan COVID-19. Pemerintah telah membuat kebijakan protokol kesehatan COVID-19 guna mengendalikan laju transmisi. Kepatuhan masyarakat akan sangat membantu menekan laju penularan. Penelitian ini bertujuan mengetahui determinan kepatuhan terhadap protokol kesehatan COVID-19. Penelitian ini merupakan Systematic Literature Review (SLR) dengan metode PRISMA. Kata kunci yang digunakan untuk penelusuran artikel adalah determinan kepatuhan protokol kesehatan COVID-19, sikap, motivasi pencegahan COVID-19, dan determinants of compliance with COVID19. Google Scholar, ResearchGate, dan PubMed merupakan data base jurnal yang digunakan untuk melakukan pencarian literatur dan dari hasil pencarian ditemukan 5 artikel yang relevan. Kesimpulannya adalah determinan kepatuhan terhadap protokol kesehatan COVID-19 yaitu sikap, motivasi, pengetahuan, usia, pendidikan, lingkungan sosial, dan ketersediaan sarana. Rekomendasinya adalah diharapkan masyarakat mematuhi protokol kesehatan COVID-19 yaitu mencuci tangan, menggunakan masker, menjaga jarak, dan menjauhi kerumunan.
\end{abstract}

Kata Kunci: COVID-19, Determinan Kepatuhan, Protokol Kesehatan.

\begin{abstract}
Non-compliance with the COVID-19 health protocol in Indonesia is still the cause of the high number of COVID-19 transmissions. The government has made a COVID-I9 health protocol policy to control the rate of transmission. Community compliance will greatly help reduce the rate of transmission. This study aims to determine the determinants of compliance with the COVID- 19 health protocol. This research is a Systematic Literature Review (SLR) with method PRISMA. The keywords used to search the articles are determinants of compliance with COVID-19 health protocols, attitudes, motivation to prevent COVID-19, and determinants of compliance with COVID-19. Google Scholar, ResearchGate, and PubMed are journal data bases that are used to conduct a literature search and from the search results found 5 relevant articles. The conclusion is that the determinants of compliance with the COVID-19 health protocol are attitudes, motivation, knowledge, age, education, social environment, and availability of facilities. The recommendation is that the public is expected to comply with the COVID-19 health protocol, namely washing hands, wearing masks, maintaining distance, and staying away from crowds.
\end{abstract}

Keywords: COVID-19, Determinants of Compliance, Health Protocol.

Korespondensi*: Tanto, Program Studi llmu Kesehatan Masyarakat, Sekolah Pascasarjana Universitas Muhammadiyah Prof. Dr. Hamka, Jl. Warung Jati Barat, Blok Darul Muslimin No. 7 RT 2/RW 5, Kalibata, Kec. Pancoran, Kota Jakarta Selatan, DKI Jakarta 12740, E-mail: tantomahmud83@gmail.com, No.Telp: (02I)79I84063 


\section{Pendahuluan}

Pada awal tahun 2020 dunia mengalami kondisi yang sangat krusial yaitu munculnya wabah virus corona (COVID-19). Wabah COVID-19 pertama kali dideteksi di Kota Wuhan, Hubei, Cina pada 1 Desember 2019. ${ }^{1}$ World Health Organization (WHO) menetapkan COVID-19 sebagai Kedaruratan Kesehatan Masyarakat yang Meresahkan Dunia (KKMMD) pada tanggal 30 Januari 2020. ${ }^{2}$ Surveilans WHO per 2 April 2020, di daerah pasifik barat, Tiongkok menempati urutan pertama dengan total kasus terkonfirmasi 82.724 dan meninggal 3.327 orang. Thailand menempati urutan pertama di Asia Tenggara dengan total terkonfirmasi 1.771 , meninggal $12 .{ }^{3}$ Case Fatality Rate akibat COVID- 19 di Indonesia terletak pada rentang persentase 3-4\%, angka ini cukup besar dibandingkan negara lain seperti Amerika hanya sekitar 3\%. Tingginya angka CFR ini, pemerintah wajib menerapkan protokol kesehatan COVID-19, yakni meningkatkan kepatuhan memakai masker, menjaga jarak, mencuci tangan dan menjauhi kerumunan.

Berdasarkan data BPS RI tahun 2020, perempuan lebih patuh terkait penerapan protokol dibanding laki-laki yaitu menggunakan masker perempuan $94,8 \%$ dibanding laki-laki 88,5\%, menggunakan hand sanitizer perempuan sebesar $83,6 \%$ dan laki-laki sebesar 70,5\%, mencuci tangan perempuan sebesar $80,1 \%$ dan laki-laki sebesar $69,5 \%$, menghindari jabat tangan perempuan sebesar $87,2 \%$ dan laki-laki sebesar 75,3\%, menghindari kerumunan (perempuan $81,2 \%$ vs. laki-laki $71,1 \%$ ), menjaga jarak (perempuan $77,5 \%$ vs. laki-laki $68,7 \%$ ), persepsi sangat tidak mungkin dan tidak mungkin terinfeksi yaitu menurut level pendidikan SD $33,69 \%$, SMP 32,58\%, SMA/SMK $25,46 \%$, Diploma/Sarjana $13,41 \%$ artinya semakin tinggi pendidikan, semakin meyakini bahwa COVID-19 berbahaya dan mudah menular. Menurut kelompok umur 17-30 tahun sebesar 20,2\%, 31-45 tahun
$15,3 \%$, 46-60 tahun 16,2\%, >60 tahun $17,4 \%$, dan media paling berpengaruh yaitu media sosial $34,05 \%$, TV $23,72 \%$, Whatsapp 12,30\%. ${ }^{5}$ Penelitian Desy Ria Simanjuntak, dkk terdapat sebesar $22 \%$ yang tidak melakukan protokol kesehatan COVID-19 cuci tangan. ${ }^{6}$

Dalam upaya melaksanakan pencegahan penularan COVID-19, Kemenkes mengeluarkan Surat Edaran Nomor HK.02.01/MENKES/199/2020 yaitu himbauan yang harus dipatuhi semua kalangan masyarakat. ${ }^{7}$ Selain himbawan pemerintah, dalam upaya meningkatkan kepatuhan protokol kesehatan, perlu juga memperhatikan faktor-faktor yang mempengaruhi kepatuhan COVID-19 antara lain: sikap, motivasi, pengetahuan, usia, pendidikan, lingkungan sosial, dan ketersediaan sarana.

COVID-19 selain berdampak terhadap kesehatan juga berdampak terhadap kondisi sosial ekonomi. Dampak sosial sangat dirasakan oleh masyarakat seperti panik, cemas dan stress. Dampak ekonomi seperti pemutusan hubungan kerja (PHK), menurunnya pendapatan, dan lain-lain. ${ }^{8}$ Menurut Salma Matla Ilpaj dan Nunung Nurwati bahwa tingginya tingkat kematian akibat COVID-19 disebabkan oleh faktor internal seperti penyakit bawaan, kurangnya awareness dan faktor eksternal seperti sarana rumah sakit yang kurang mencukupi, peraturan pemerintah yang belum efektif, dan sebagainya. ${ }^{8}$ Menurut Chandrayani Simanjorang, dkk terkait pencegahan COVID-19 bahwa kebanyakan responden berperilaku baik. ${ }^{9}$

Maya Eka Lestari, dkk juga menyatakan faktor-faktor risiko yang signifikan antara lain adalah perceived severity, self efficacy, motivasi, niat berperilaku, berita hoax, dan sumber informasi yang didapatkan ${ }^{10}$. Berdasarkan hasil literature review jurnal oleh Wuri Ratna Hidayani bahwa faktor-faktor risiko yang berhubungan dengan COVID-19 adalah karakteristik individu seperti umur dan jenis kelamin, infeksi nosokomial, penyakit komorbid dan riwayat merokok. ${ }^{11}$ 
Berdasarkan studi data-data sekunder di website survey Badan Pusat Statistik oleh Desy Ria Simanjuntak, dkk mengenai COVID-19 disimpulkan bahwa usia $>60$ tahun lebih patuh terhadap penerapan protokol kesehatan. Pada variabel lain yaitu perempuan juga lebih patuh terhadap penerapan protokol kesehatan. ${ }^{6}$

Berdasarkan yang telah diuraikan di atas, maka penulis tertarik untuk melakukan literature review penelitianpenelitian terdahulu yang relevan dengan tema determinan kepatuhan terhadap protokol kesehatan COVID-19.

\section{Metode}

Literature review ini hanya berfokus pada variabel independen. Penelitian akan berfokus pada penelusuran determinan kepatuhan terhadap protokol kesehatan COVID-19 di Indonesia. Kriteria inklusi yang berupa teks lengkap artikel yang relevan dan studi kasus penelitian berada di Indonesia. Artikel yang terpilih melalui proses penyaringan melalui data base Google Schooler, PubMed, dan ResearchGate kemudian dikaji dengan membaca seluruh teks terutama pada bagian hasil untuk mencari variabelvariabel yang mempengaruhi kepatuhan terhadap protokol kesehatan COVID-19.

Literature review ini menggunakan metode PRISMA. Jurnal penelitian tahun 2020 dengan rancangan penelitian analitik. Teknik pengumpulan data yaitu melakukan pengkajian informasi 30 artikel dengan penulusuran dengan bantuan internet agar dapat memperkuat argumentasi artikel ini.

Penelitian ini menggunakan tiga data-base jurnal yaitu Google Scholar, ResearchGate, dan PubMed. Dan menggunakan aplikasi Mendeley sebagai reference manager, dimulai dengan membuka aplikasi mendeley, pada mendeley desktop klik help, lalu klik mendeley website. Ketik judul artikel yang relevan, kemudian klik cari. Sedangkan pada data base Google Scholar, ResearchGate, dan PubMed, tinggal mengeketik judul artikel yang relevan dan cari. Kriteria yang ditetapkan peneliti yaitu artikel harus relevan dengan topik, teks lengkap dan berkaitan dengan determinan kepatuhan protokol kesehatan COVID-19 dan penelitian berada di Indonesia. Kemudian rentang tahun publikasi yaitu Januari 2016-Desember 2021. Pencarian literatur dilakukan dengan menggunakan kata kunci yaitu determinan kepatuhan protokol kesehatan COVID-19, sikap, motivasi pencegahan COVID-19, dan determinants of compliance with COVID19. Setiap artikel dikaji terlebih dahulu, kemudian artikel yang relevan didownload, lalu copy paste menjadi satu file pada laptop. Dari hasil pencarian ditemukan 30 artikel yang dianggap relevan. Kemudian dari jumlah tersebut diseleksi kembali dan ditentukan 5 artikel yang dianggap memiliki kriteria inklusi. Semua data disaring dan dikumpulkan secara manual.

\section{Hasil}

Literature rieview ini disusun melalui proses kajian artikel yang telah diseleksi dan mengacu pada tujuan penelitian. Kata kunci yang dimasukan yaitu: determinan kepatuhan protokol kesehatan COVID-19, sikap, motivasi pencegahan COVID-19, dan determinants of compliance with COVID-19. Penulis mencari artikel menggunakan tiga data base yaitu PubMed, ResearchGate, dan Google Scholar, dan berhasil mengidentifikasi 441 artikel, kemudian melakukan seleksi kemiripan didapatkan 395, lalu melakukan skrining judul dan abstrak didapatkan 56 artikel yang relevan, setelah dinilai kelayakannya diperoleh 30 artikel. Sesuai dengan inklusi yaitu untuk mengetahui determinan yang mempengaruhi kepatuhan protokol kesehatan COVID-19 didapat 5 artikel. Literatur-literatur yang diperoleh disintesis mengunakan metode narasi dengan mengelompokan data hasil ekstraksi yang mirip dengan hasil yang diukur untuk menjawab tujuan penelitian. 


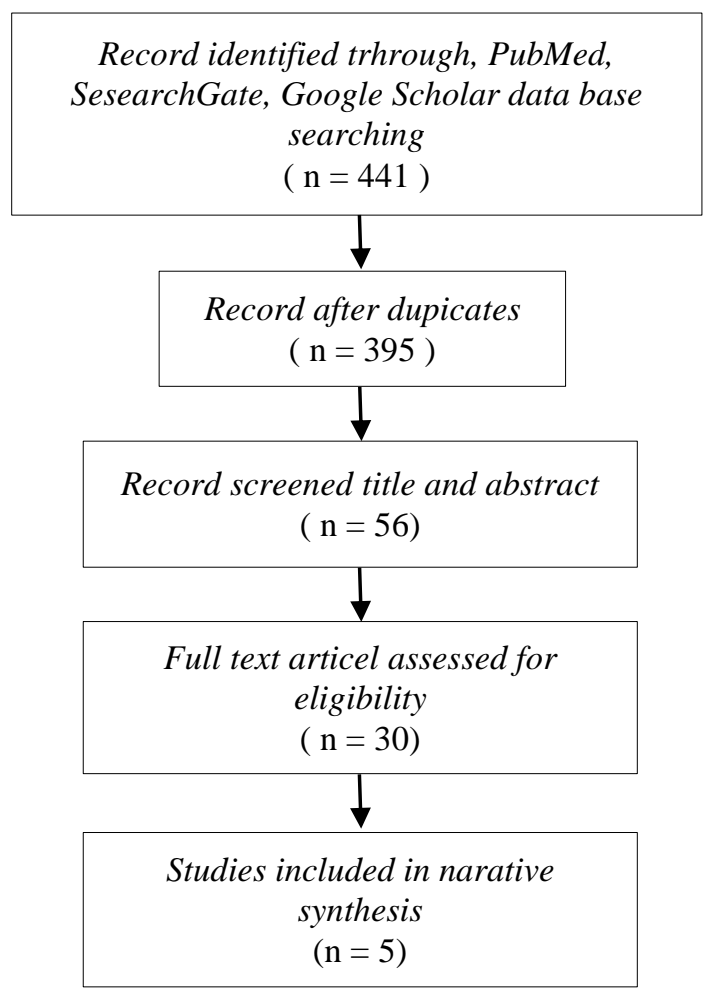

Gambar 1. Diagram Alir Pencarian dan Seleksi Artikel

Hasil artikel penelitian yang sesuai dengan kriteria inklusi digabungkan dalam tabel yang meliputi nama dan tahun penelitian, nama jurnal, judul penelitian, variabel yang diteliti, desain studi, sampel penelitian, metode statistik, hasil analisa statistik, hasil penelitian, kesimpulan penelitian, dan saran yang disajikan dalam tabel 1.

Penelitian Sarah, et al memiliki karakteristik responden umur $(21-30=35$, $31-40=25)$, pendidikan (D3=5, $\mathrm{S} 1=41$, $\mathrm{S} 2=3, \mathrm{SD}=6, \mathrm{SMA}=1, \mathrm{SMP}=4)$, pekerjaan (Honorer $=6, \quad$ IRT $=45, \quad$ Pedagang=3, PNS=6). Penelitian Novi Afrianti, et al memiliki karakteristik responden usia (Remaja $=45, \quad$ Dewasa $=118)$, suku (Aceh=132, Lainnya=31), pendidikan (Tinggi=123, Rendah=40), jenis kelamin (Laki-laki=50, Perempuan=112), pekerjaan (Bekerja=43, Belum Bekerja=120), status (Belum menikah=124, Menikah=39). Tariana Ginting, et al memiliki karakteristik responden jenis kelamin (Laki-laki=30, Perempuan=103), umur
$(20-29=22, \quad 30-39=53, \quad \geq 40=58)$, sikap (Kurang=11, Baik=19), pendidikan $(\mathrm{SD}=10, \quad \mathrm{SMP}=21, \quad \mathrm{SMA}=62$, Akademik/Perguruan Tinggi=40).

Ilham Mirzaya Putra, et al memiliki karakteristik responden jenis kelamin (Laki-laki $=56$, Perempuan=40), usia (20$30=36, \quad 31-40=43, \quad 41-50=11, \quad>50=6)$, pendidikan $\quad(\mathrm{SD}=0, \quad \mathrm{SMP}=1, \quad \mathrm{SMA}=8$, $\mathrm{S} 1=59$, Pascasarjana $=28$ ), pekerjaan (PNS/TNI/Polri=30, Guru=29, Pegawai Swasta $=10, \quad$ Pedagang $=3, \quad$ Buruh $=1$, Lainnya $=18$, Tidak bekerja $=5$ ), jumlah penghasilan $(<3$ juta $=57,3-5$ juta $=17,>5$ juta=22). Penelitian Felix Kasim, et al tidak menampilkan tabel karakteristik responden. Kelima penelitian tersebut memuat hasil penelitian asli, mengkaji sebuah masalah baru, menjelaskan masalah kepatuhan protokol kesehatan yang pada dasarnya memberikan edukasi kepada masyarakat luas. Kemudian memliki variabel independen dan variabel dependen, subjek penelitian yaitu manusia 


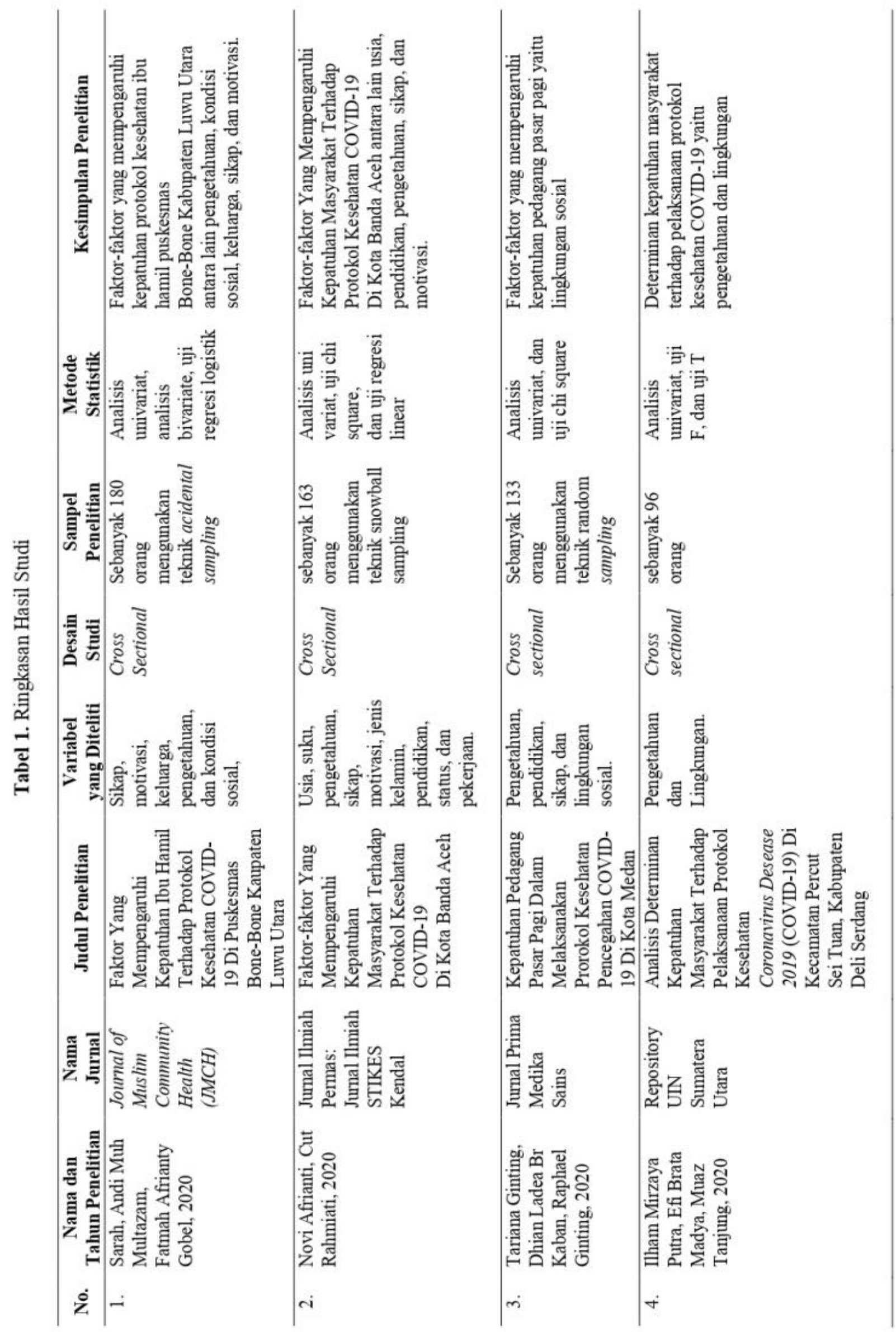




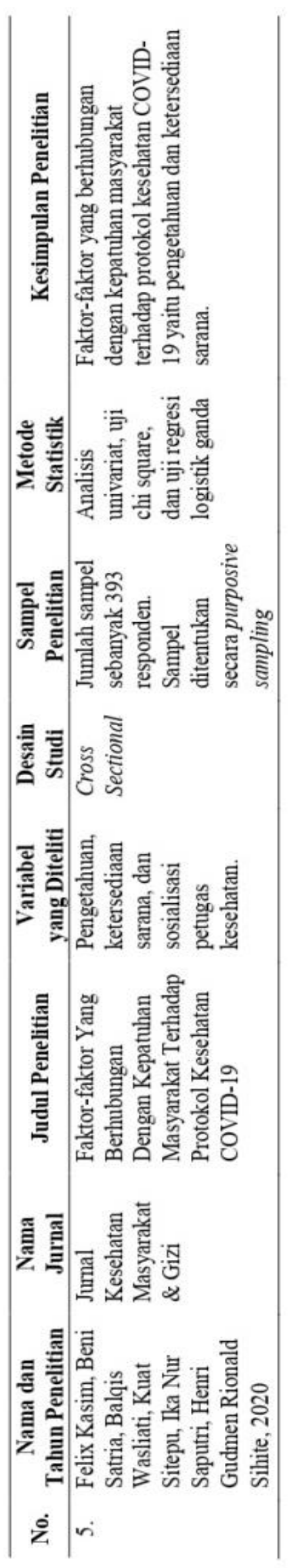

sehingga sangat diharapkan memperhatikan prosedur-prosedur yang sudah ditetapkan agar tidak terjadi pelanggaran.

Penelitian Novi Afrianti, et al memiliki paling banyak variabel independen yaitu sembilan variabel antara lain usia, suku, pengetahuan, sikap, motivasi, jenis kelamin, pendidikan, status, dan pekerjaan, sedangkan Ilham Mirzaya Putra, et al memiliki paling sedikit variabel independen yaitu hanya dua variabel yaitu pengetahuan dan lingkungan. Penelitian Sarah, et al memiliki lima variabel yaitu sikap, motivasi, keluarga, pengetahuan, dan kondisi sosial, penelitian Tariana Ginting, et al memiliki empat variabel yaitu pengetahuan, pendidikan, sikap, dan lingkungan sosial, dan Felix Kasim, et al memiliki tiga variabel yaitu pengetahuan, ketersediaan sarana, dan sosialisasi petugas kesehatan. Kelima penelitian menggunakan desain studi cross sectional, penelitian Felix Kasim, et al mempunyai sampel paling banyak 393 orang, sedangkan Ilham Mirzaya Putra, et al mempunyai sampel paling sedikit yaitu 96 orang.

Penelitian Sarah, et al memiliki sampel sebanyak 180 orang, Novi Afrianti, et al memiliki sampel sebanyak 163 orang, dan Tariana Ginting, et al memiliki sampel sebanyak 133 orang. Metode statistik yang digunakan dari kelima penelitian tersebut yaitu metode kuantitatif dengan uji univariat, uji bivariat, dan uji multivariat. Sarah et al mendapatkan hasil analisis sikap (sig=0,001), motivasi (sig=0,001), keluarga $(\operatorname{sig}=0,001), \quad$ pengetahuan ( $\operatorname{sig}=0,001)$, dan kondisi sosial (sig $=0,008)$. Semua variabel mempunyai nilai sig $<0,05$ sehingga ada pengaruh sikap, motivasi, keluarga, pengetahuan, dan kondisi sosial terhadap kepatuhan protokol kesehatan COVID-19. Novi Afrianti, et al mendapatkan hasil usia $(\mathrm{p}=0,002)$, suku $(\mathrm{p}=0,107)$, pengetahuan $(\mathrm{p}=0,007), \quad$ sikap $(\mathrm{p}=0,048)$, motivasi $(\mathrm{p}=0,035)$, jenis kelamin $(\mathrm{p}=0,884)$, pendidikan $(\mathrm{p}=0,023)$, status $(\mathrm{p}=0,057)$, 
dan pekerjaan $(\mathrm{p}=0,842)$ sehingga ada pengaruh usia, pendidikan, pengetahuan, sikap, dan motivasi terhadap kepatuhan protokol kesehatan COVID-19 sebab nilai $\mathrm{p}<0,05$, kemudian tidak ada pengaruh suku, jenis kelamin, status, dan pekerjaan terhadap kepatuhan protokol kesehatan sebab nilai $\mathrm{p}>0,05$. Tariana Ginting, et al mendapatkan hasil pengetahuan $(\mathrm{p}=0,268)$, pendidikan $(\mathrm{p}=0,918)$, sikap $(\mathrm{p}=0,104)$, dan lingkungan sosial $(\mathrm{p}=0,017)$. Tidak ada pengaruh tingkat pendidikan, pengetahuan, dan sikap dengan kepatuhan $\mathrm{p}>0,05$, tetapi ada pengaruh faktor

\section{Pembahasan}

Menurut Sarah, et al variabel sikap dan motivasi mempengaruhi kepatuhan terhadap protokol kesehatan COVID-19. Variabel-variabel lain yang mempengaruhi kepatuhan protokol kesehatan yaitu keluarga, pengetahuan, dan kondisi sosial. ${ }^{12}$ Penelitian Novi Afrianti, et al juga menyatakan variabel sikap dan motivasi mempengaruhi kepatuhan masyarakat terhadap protokol kesehatan. Variabelvariabel lain yang mempengaruhi kepatuhan protokol kesehatan yaitu usia, pendidikan, dan pengetahuan. ${ }^{13}$ Penelitianpenelitian tersebut sejalan dengan hasil penelitian Nurul Ainin, et al yang menyatakan sikap berhubungan dengan perilaku pencegahan COVID-19. ${ }^{14}$ Penelitian Nismawati dan Marhtyni juga menemukan hasil yang sama yaitu sikap berhubungan dengan penerapan protokol kesehatan. ${ }^{2}$ Penelitian Maya Eka Lestari, et al menyatakan motivasi berhubungan dengan perilaku pencegahan COVID-19. ${ }^{10}$

Menurut Nemcomb sikap merupakan kesiapan untuk bereaksi terhadap objek di lingkungan tertentu dalam hal ini kepatuhan terhadap protokol kesehatan. ${ }^{15}$ Sikap merupakan suatu bentuk penilaian seseorang terhadap stimulus. Sikap sejalan dengan pengetahuan dimana seseorang harus mengetahui terlebih dahulu stimulusnya baru kemudian memberikan penilaian. ${ }^{15}$ Sikap ada 2 yaitu sikap negatif dan sikap positif. Sikap positif lingkungan sosial dengan kepatuhan $\mathrm{p}<0,05$.

Ilham Mirzaya Putra, et al mendapatkan hasil pengetahuan dan lingkungan sig $=0,000 \quad$ sehingga berpengaruh signifikan terhadap kepatuhan protokol kesehatan COVID-19. Felix Kasim, et al mendapatkan hasil variabel pengetahuan $\mathrm{p}=0,012$, ketersediaan sarana $\mathrm{p}=0,003$, sehingga variabel pengetahuan dan ketersediaan sarana mempengaruhi kepatuhan protokol kesehatan sebab nilai $\mathrm{p}<0,05$.

menunjukkan adanya kepercayaan terhadap kebijakan kepatuhan protokol kesehatan. Individu dengan sikap positif tinggi cenderung patuh terhadap protokol kesehatan. Menurut Lawrence Green faktor motivasi atau pendorong merupakan faktor yang memperkuat terjadinya suatu perilaku, jadi faktor ini terwujud dalam perilaku masyarakat. ${ }^{16}$ Menurut teori Health Belief Model (HBM), faktor motivasi merupakan faktor yang cukup kuat untuk mencapai kondisi yang sehat ${ }^{17}$. Individu dengan motivasi tinggi cenderung patuh terhadap protokol kesehatan.

Penelitian Sarah, et al menyatakan variabel pengetahuan mempengaruhi kepatuhan terhadap protokol kesehatan COVID-19. Variabel-variabel lainnya yaitu sikap, motivasi, keluarga, dan kondisi sosial. ${ }^{12}$ Penelitian Novi Afrianti, et al juga menyatakan variabel pengetahuan mempunyai pengaruh. Variabel lain yang mempunyai pengaruh yaitu sikap, motivasi, usia, dan pendidikan. ${ }^{13}$ Ilham Mirzaya Putra, et al menyatakan faktor pengetahuan mempunyai pengaruh terhadap kepatuhan masyarakat. Variabel lain yang berpengaruh yaitu faktor lingkungan. ${ }^{18}$ Felix Kasim, et al juga menyatakan faktor pengetahuan mempengaruhi kepatuhan terhadap protokol kesehatan. Faktor lain adalah ketersediaan sarana. ${ }^{19}$

Werku Etafa, et al menyatakan pelatihan dan bahan bacaan untuk 
meningkatkan pengetahuan berhubungan secara signifikan dengan tindakan pencegahan COVID-19. ${ }^{20}$ Penelitian Bao Liang Zhong, et al menyatakan pengetahuan berhubungan dengan praktik pencegahan terhadap COVID-19. ${ }^{21}$ Pengetahuan merupakan hasil dari penginderaan terhadap suatu objek dalam hal ini menyangkut masalah kesehatan ${ }^{15}$. Individu yang mengetahui banyak informasi terkait COVID-19 baik itu pada media cetak maupun elektronik cenderung lebih patuh terhadap protokol kesehatan. Individu dengan pengetahuan cukup akan lebih patuh dibandingkan dengan individu dengan pengetahuan kurang. Menurut Notoatmojo, 2010 pengetahuan merupakan dasar untuk mengambil keputusan dan menentukan tindakan terhadap masalah yang dihadapi. ${ }^{16}$

Penelitian Novi Afrianti, et al menyatakan variabel usia mempunyai pengaruh. Variabel lain adalah sikap, motivasi, pendidikan, dan pengetahuan. ${ }^{13}$ Hasil ini didukung oleh penelitian Salah Alghanem, at al menyatakan usia berhubungan dengan tindakan pengendalian COVID-19. ${ }^{22}$ Penelitian Fitriyanti Maldiansah Akmal juga menyatakan hasil yang sejalan yaitu umur mempengaruhi perilaku masyarakat menghadapi pandemi COVID-19. ${ }^{23}$ Menurut Rosenstock usia dapat merubah perilaku individu ${ }^{17}$. Individu yang memiliki usia tua cenderung patuh terhadap protokol kesehatan karena lebih berisiko terhadap COVID-19.

Penelitian Novi Afrianti, et al menyatakan variabel pendidikan mempunyai pengaruh. Variabel lain adalah sikap, motivasi, usia, dan pengetahuan. ${ }^{13}$ Hasil ini didukung oleh penelitian Dyah Restuning Prihati, et al menyatakan variabel pendidikan berhubungan dengan perilaku pencegahan COVID-19. ${ }^{24}$ Penelitian Fitriyanti Maldiansah Akmal juga menyatakan hasil yang sejalan yaitu pendidikan mempengaruhi perilaku masyarakat menghadapi pandemi COVID$19 .^{23}$ Menurut Rosenstock faktor pendidikan dapat merubah perilaku seseorang ${ }^{17}$. Individu dengan tingkat pendidikan tinggi cenderung patuh terhadap protokol kesehatan. Individu dengan pendididkan tinggi lebih paham informasi tentang COVID-19 dibandingkan dengan individu dengan pendidikan rendah.

Sarah, et al menyatakan lingkungan sosial mempunyai pengaruh. Variabel lain yang berpengaruh yaitu sikap, motivasi, keluarga, dan pengetahuan. ${ }^{12}$ Tariana Ginting, et al juga menyatakan hal yang sama. ${ }^{25}$ Ilham Mirzaya Putra, et al menyatakan faktor lingkungan sosial mempunyai pengaruh. ${ }^{18}$

Hasil penelitian-penelitian tersebut sejalan dengan penelitian Werku Etafa, et al menyatakan dukungan dari manajemen rumah sakit berhubungan dengan tindakan pencegahan COVID-19. ${ }^{20}$ Perilaku kesehatan seseorang salah satunya ditentukan oleh dukungan dari masyarakat. ${ }^{15}$ Seseorang barangkali tidak mau patuh terhadap protokol kesehatan karena tidak adanya dukungan sosial. Adanya dukungan dari keluarga, teman, dan tenaga kesehatan akan membuat seseorang menjadi patuh terhadap protokol kesehatan.

Felix Kasim, et al menyatakan bahwa faktor ketersediaan sarana mempunyai pengaruh. Faktor ketersediaan sarana merupakan faktor paling berpengaruh, artinya responden yang tidak memiliki ketersediaan sarana berpeluang untuk tidak patuh terhadap protokol kesehatan COVID-19. ${ }^{19}$ Hasil yang sama oleh Nismawati dan Marhtyni menyatakan faktor sarana prasarana berhubungan dengan penerapan protokol kesehatan. ${ }^{2}$ Perilaku terbentuk salah satunya ada tidaknya fasilitas atau sarana-sarana kesehatan sebagai faktor pendukung. ${ }^{17}$ Ketersediaan fasilitas akan memperkuat terbentuknya perilaku kepatuhan protokol kesehatan. Sarana yang kurang dan tidak sesuai akan menurunkan tingkat kepatuhan terhadap protokol kesehatan. 


\section{Kesimpulan}

Berdasarkan hasil dan pembahasan, dapat disimpulkan bahwa determinan kepatuhan terhadap protokol kesehatan COVID-19 yaitu sikap, motivasi, pengetahuan, usia, pendidikan, lingkungan sosial dan ketersediaan sarana. Pemerintah adalah pembuat peraturan namun peraturan-peraturan yang sudah dibuat tidak akan berjalan tanpa kesadaran masayarakat. Pemerintah tidak bisa mengontrol penerapan protokol kesehatan COVID-19 secara menyeluruh, oleh karena itu peran aktif masyarakat sangat diperlukan yaitu menunjukkan sikap yang positif, motivasi yang tinggi, meningkatkan pengetahuan terhadap virus corona, mencari dukungan sosial, dan memfasilitasi secara mandiri sarana prasarana yang diperlukan karena pemerintah tidak mempunyai anggaran yang cukup, sehingga masyarakat akan dapat mencegah penyebaran COVID-19. Diharapkan kepada masyarakat agar bersinergi dengan pemerintah sebagai pembuat kebijakan, masyarakat mematuhi peraturan-peraturan terkait protokol kesehatan COVID-19 sehingga dapat memutus mata rantai penyebaran virus tersebut. Kemudian diharapkan kepada penelitian selanjutnya agar memperkaya lagi mengenai isu-isu COVID-19, karena virus ini terus bermutasi, beda varian beda pula pencegahan dan pengendaliannya.

\section{Daftar Pustaka}

1. Fitri BM, Widyastutik O, Arfan I. Penerapan protokol kesehatan era new normal dan risiko covid-19 pada mahasiswa. Ris Inf Kesehat [Internet]. 2020;9(2):143. Available from: http://stikes-

hi.ac.id/jurnal/index.php/rik/article/view/460

2. Nismawati N, Marhtyni M. Faktor Yang Berhubungan Dengan Penerapan Protokol Kesehatan Pada Pelaku Usaha Mikro Selama masa Pandemi Covid -19. UNM Environ Journals [Internet]. 2020;3(3):116. Available from:

http://103.76.50.195/UEJ/article/view/16210

3. WHO. Coronavirus disease 2019 (COVID-19) Situation Report - 73 Data. World Heal Organ [Internet]. 2020;2019(March):2633. Available from: https://www.who.int/emergencies/diseases/no vel-coronavirus-2019

4. Afro RC, Isfiya A, Rochmah TN. Analisis Faktor Yang Mempengaruhi Kepatuhan Terhadap Protokol Kesehatan Saat Pandemi Covid-19 Pada Masyarakat Jawa Timur: Pendekatan Health Belief Model. J Community Ment Heal Public Policy [Internet]. 2021;3(1):1-10. Available from: http://cmhp.lenterakaji.org/index.php/cmhp/ar ticle/view/43

5. Tim BPS Covid-19. Perilaku Masyarakat di Masa Pandemi COVID-19 [Internet]. BPS RI; 2020. Available from: https://covid19.bps.go.id/

6. Simanjuntak DR, Napitupulu TM, Wele AM, Yanie R. Gambaran Kepatuhan Masyarakat Menerapkan Protokol Kesehatan COVID-19 Di Tempat Umum Periode September 2020 di DKI Jakarta. Fak Kedokt Univ Kristen Indones [Internet]. 2020;(September 2020). Available

from: http://repository.uki.ac.id/3191/1/ManuscriptP enelitianGambaranKepatuhan.pdf

7. Rizqiyani Khoiriyah. Efektivitas Media Terhadap Perubahan Perilaku Pada Startegi Pemasaran Sosial Muhammadiyah Covid-19 Command Center (MCCC) Di DKI Jakarta. Orphanet Journal of Rare Diseases. Universitas Muhammadiyah Prof.Dr.Hamka; 2020.

8. Ilpaj SM, Nurwati N. Analisis Pengaruh Tingkat Kematian Akibat Covid-19 Terhadap Kesehatan Mental Masyarakat Di Indonesia. Focus J Pekerj Sos [Internet]. 2020;3(1):16. Available from: http://journal.unpad.ac.id/focus/article/view/2 8123

9. Simanjorang C, Tooy G, Wuaten G, Pangandaheng N. Pemahaman Dan Perilaku Pencegahan Coronavirus Desease 2019 Di Kalangan Civitas Akademika Politeknik Negeri Nusa Utara Pada Masa New Normal Tahun 2020. 2020;1-7. Available from: http://ejournal.polnustar.ac.id/jis/article/view/317

10. Lestari EM, Suwarni L, Selviana S, Ruhama' U, Mawardi M. Faktor Yang Berhubungan Dengan Perilaku Pencegahan Covid-19 Di Kota Pontianak. J Kesehat [Internet]. 2021;11(3):335. Available from: https://www.researchgate.net/publication/3491 08053_Faktor_Yang_Berhubungan_Dengan_ Perilaku_Pencegahan_Covid19_Di_Kota_Pontianak

11. Hidayani WR. Faktor Faktor Risiko Yang Berhubungan Dengan COVID 19: Literature Review. J Untuk Mayarakat Sehat [Internet]. 2020;4(2):120-34. Available from: http://ejournal.urindo.ac.id/index.php/jukmas/ 
article/view/1015/696

12. Sarah, Multazam AM, Gobel FA. Faktor Yang Mempengaruhi Kepatuhan Ibu Hamil Terhadap Protokol Kesehatan Covid-19 Di Puskesmas Bone-Bone Kabupaten Luwu Utara. J Muslim Community Heal [Internet]. 2021;2(1):92-107. Available from: http://pascaumi.ac.id/index.php/jmch/article/view/490/54 1

13. Novi Afrianti CR. Faktor-faktor yang mempengaruhi kepatuhan masyarakat terhadap protokol kesehatan covid-19. 2021;001:113-24. Available from: http://journal.stikeskendal.ac.id/index.php/PS KM/article/view/1045/647

14. Aini N-, Purwasari MD. Sikap dan Perilaku Pencegahan Covid-19 di Desa Kemuningsari Kidul Kabupaten Jember. J Kesehat [Internet]. 2021;8(3):171-7. Available from: https://scholar.google.com/scholar?hl=id\&as_ $\mathrm{sdt}=0 \% 2 \mathrm{C} 5 \& \mathrm{q}=$ Sikap + dan+Perilaku+Pencega han+Covid-

19+di+Desa+Kemuningsari+Kidul+Kabupate $\mathrm{n}+\mathrm{Jember} \& \mathrm{btnG}=$

15. Adventus, Jaya IMM, Mahendra D. Buku Ajar Promosi Kesehatan [Internet]. Pusdik SDM Kesehatan. Jakarta; 2019. Available from: http://repository.uki.ac.id/2759/1/Bukumodulp romosikesehatan.pdf

16. Pakpahan M, Siregar D, Susilawaty A, Mustar T, Ramdany R, Manurung EI, et al. Promosi Kesehatan \& Prilaku Kesehatan [Internet]. Jakarta: EGC. Yayasan Kita Menulis; 2021. Available from: https://kitamenulis.id/2021/02/19/promosikesehatan-dan-perilaku-kesehatan/

17. Irwan. Etika dan Perilaku Kesehatan. Yogyakarta: Absolute Media; 2017.

18. Putra I mirzaya. Judul: Analisis Determinan Kepatuhan Masyarakat Kecamatan Percut Sei Tuan, Kabupaten Deli. 2020;2019. Available from:

http://repository.uinsu.ac.id/10662/1/Laporan Penelitian FINAL.pdf

19. Kasim F, Satria B, Wasliati B, Sitepu K, Nur Saputri I, Sihite HG. Faktor-Faktor Yang Berhubungan Dengan Kepatuhan Masyarakat
Terhadap Protokol Kesehatan Covid-19. J Kesmas Dan Gizi [Internet]. 2021;3(2):20712. Available from: https://ejournal.medistra.ac.id/index.php/JKG/ article/view/687

20. Etafa W, Gadisa G, Jabessa S, Takele T. Healthcare workers' compliance and its potential determinants to prevent COVID-19 in public hospitals in Western Ethiopia. BMC Infect Dis [Internet]. 2021;21(1):1-8. Available from: https://www.ncbi.nlm.nih.gov/pmc/articles/P MC8132019/pdf/12879_2021_Article_6149.p df

21. Zhong BL, Luo W, Li HM, Zhang QQ, Liu $\mathrm{XG}, \mathrm{Li}$ WT, et al. Knowledge, attitudes, and practices towards COVID-19 among chinese residents during the rapid rise period of the COVID-19 outbreak: A quick online crosssectional survey. Int $\mathrm{J}$ Biol Sci [Internet]. 2020;16(10):1745-52. Available from: https://www.ncbi.nlm.nih.gov/pmc/articles/P MC7098034/pdf/ijbsv16p1745.pdf

22. Alghanem S, Falamarzi H. Bird' s-Eye View of COVID-19 Knowledge, Attitude and Practice Among Emergency Physicians in the Kingdom of Bahrain: A Cross- Sectional Study. Open Access Emerg Med [Internet]. 2021;(June). Available from: https://www.ncbi.nlm.nih.gov/pmc/articles/P MC8449688/pdf/oaem-13-415.pdf

23. Akmal FM. Hubungan Persepsi Dengan Perilaku Masyarakat Menghadapi Pandemic Covid-19 Di Kelurahan Gambir TAHUN 2020. UHAMKA; 2020.

24. Prihati DR, Wirawati MK, Supriyanti E. Analisis Pengetahuan Dan Perilaku Masyarakat Di Kelurahan Baru Kotawaringin Barat Tentang Covid 19. Malahayati Nurs J [Internet]. 2020;2(4):780-90. Available from: http://www.ejurnalmalahayati.ac.id/index.php/ manuju/article/view/3073/pdf

25. Ginting T, Ladea D, Kaban B, Ginting R. Kepatuhan pedagang pasar pagi dalam melaksanakan protokol kesehatan pencegahan COVID-19. 2021;03(1):6-12. Available from: http://jurnal.unprimdn.ac.id/index.php/JPMS/a rticle/view/1649/927 